\title{
Update on current management of chronic kidney disease in patients with HIV infection
}

\author{
Nina E Diana \\ Saraladevi Naicker \\ Department of Internal Medicine, \\ Faculty of Health Sciences, University \\ of the Witwatersrand, Johannesburg, \\ South Africa
}

This article was published in the following Dove Press journal: International Journal of Nephrology and Renovascular Disease 16 September 2016

Number of times this article has been viewed
Correspondence: Saraladevi Naicker Department of Internal Medicine, Faculty of Health Sciences, University of the Witwatersrand, 7 York Road, Parktown, Johannesburg 2193, South Africa Tel +27 II 7172709

Email Saraladevi.Naicker@wits.ac.za
Abstract: The prevalence of HIV-associated chronic kidney disease (CKD) varies geographically and depends on the definition of CKD used, ranging from $4.7 \%$ to $38 \%$ globally. The incidence, however, has decreased with the use of effective combined antiretroviral therapy (cART). A wide variety of histological patterns are seen in HIV-associated kidney diseases that include glomerular and tubulointerstitial pathology. In resource-rich settings, there has been a plateau in the incidence of end-stage renal disease secondary to HIV-associated nephropathy (HIVAN). However, the prevalence of end-stage renal disease in HIV-positive individuals has risen, mainly due to increased longevity on cART. There is a disparity in the occurrence of HIVAN among HIV-positive individuals such that there is an 18- to 50-fold increased risk of developing kidney disease among HIV-positive individuals of African descent aged between 20 and 64 years and who have a poorer prognosis compared with their European descent counterparts, suggesting that genetic factors play a vital role. Other risk factors include male sex, low CD4 counts, and high viral load. Improvement in renal function has been observed after initiation of cART in patients with HIV-associated $\mathrm{CKD}$. Treatment with an angiotensin-converting enzyme inhibitor/angiotensin receptor blocker is recommended, when clinically indicated in patients with confirmed or suspected HIVAN or clinically significant albuminuria. Other standard management approaches for patients with CKD are recommended. These include addressing other cardiovascular risk factors (appropriate use of statins and aspirin, weight loss, cessation of smoking), avoidance of nephrotoxins, and management of serum bicarbonate and uric acid, anemia, calcium, and phosphate abnormalities. Early diagnosis of kidney disease by screening of HIV-positive individuals for the presence of kidney disease is critical for the optimal management of these patients. Screening for the presence of kidney disease upon detection of HIV infection and annually thereafter in high-risk populations is recommended.

Keywords: chronic kidney disease, HIV infection, current management

\section{Background}

Approximately 36.9 million people worldwide were living with HIV infection in 2014, during which 2 million (1.9-2.2 million) new infections with HIV had occurred. SubSaharan Africa is the most affected region, with 25.8 (24-28.7) million people with HIV and $\sim 70 \%$ of new infections.

\section{Prevalence of HIV-associated chronic kidney disease}

The prevalence of HIV-associated chronic kidney disease (CKD) varies geographically and depends on the definition of CKD used. In North America and Europe, HIV-associated CKD prevalence ranges from 4.7\%-9.7\% (CKD being defined as 
estimated glomerular filtration rate [eGFR] $<60 \mathrm{~mL} / \mathrm{min}$ per $\left.1.73 \mathrm{~m}^{2}\right) .^{2-4}$ The prevalence increases with a change in definition to include a reduced eGFR and/or proteinuria. ${ }^{5,6}$ Using this definition, the prevalence of CKD in the US was reported at $15.5 \% .^{7}$ Approximately $16.8 \%$ of HIV-positive Chinese patients from Hong Kong were reported to have CKD (defined as eGFR $<60 \mathrm{~mL} / \mathrm{min}$ per $1.73 \mathrm{~m}^{2}$ and/or proteinuria for $>3$ months).${ }^{8}$ Screening studies defining persistent proteinuria as an indicator of CKD revealed prevalence rates of $27 \%$ in India, $12.3 \%$ in Iran, and 5.6\% in Brazil. ${ }^{9-11}$ In HIVpositive individuals in Africa, the prevalence of renal disease is widely variable: $38 \%$ in Nigeria, ${ }^{12} 33.5 \%$ in Zambia, ${ }^{13} 26 \%$ in Cote d'Ivoire, ${ }^{14} 20 \%$ in Uganda, ${ }^{15} 11.5 \%$ in Kenya, ${ }^{16}$ and $5.5 \%-6 \%$ in South Africa. ${ }^{17,18}$ This variation is attributed to genetic heterogeneity and inconsistency in access to care, initiation of combined antiretroviral therapy (cART), reporting methods, and CKD definition.

While the incidence of end-stage renal disease (ESRD) in HIV-positive individuals has decreased over time, they are still more likely than HIV-negative individuals to develop ESRD. ${ }^{19}$ There is a twofold to 20 -fold greater risk of ESRD compared with the general population, with incidence rates in the US and Europe of three to ten per 1,000 person-years in HIV-positive individuals versus 0.5 per 1,000 person-years in HIV-negative individuals. ${ }^{20-23}$ There is also a significant racial disparity in the burden of ESRD, with a six times higher risk borne by individuals of African origin. ${ }^{19,22,24}$

\section{Spectrum of HIV-associated CKD}

A wide variety of histological patterns are seen in HIVassociated kidney diseases that include glomerular and tubulointerstitial pathology (Table 1).

HIV-associated nephropathy (HIVAN) is best defined. HIVAN characteristically presents with heavy proteinuria, reduced eGFR, and echogenic kidneys on ultrasound. ${ }^{25-27}$ Histologically, HIVAN is characterized by collapsing focal segmental glomerulosclerosis (FSGS), microcystically dilated tubules, and tubulointerstitial inflammation (typically comprising macrophages and T cells; Figure 1). ${ }^{28-32}$ It usually occurs in states of advanced immunosuppression and in young adults of African ancestry. There is an 18-fold increased risk of developing HIVAN in people of African descent compared with those of European descent. ${ }^{33}$ In the US, it has been reported in 3.5\%-10\% of HIV-positive individuals. The prevalence in African biopsy series varies greatly: 5\%-27\% in Johannesburg, ${ }^{18,34,35} 55 \%-57.3 \%$ in Cape Town, ${ }^{36,37} 70 \%$ in Nigeria, ${ }^{12}$ and $83 \%$ in Durban. ${ }^{17}$ Prior to the use of cART, it progressed rapidly to ESRD. The incidence, however, has decreased with the use of effective cART. ${ }^{38-40}$
Table I Patterns of renal disease in HIV infection

\begin{tabular}{|c|c|}
\hline Renal disorder & Association/subtype \\
\hline \multicolumn{2}{|l|}{ Glomerular lesion } \\
\hline HIV FSGS or "classic" & APOLI risk variants \\
\hline HIVAN & $\begin{array}{l}\text { Mixed variant (HIV FSGS in combination } \\
\text { with a proliferative glomerulonephritis) }\end{array}$ \\
\hline HIVICD (these patients may & Mesangial proliferative \\
\hline be coinfected with hepatitis & Membranoproliferative (types I and II) \\
\hline \multirow[t]{5}{*}{$B$ or $C)$} & Lupus like \\
\hline & Exudative proliferative \\
\hline & Crescentic \\
\hline & Immunoglobulin A \\
\hline & Membranous \\
\hline Various & Minimal change disease \\
\hline glomerulonephropathies & Immunotactoid nephropathy \\
\hline (heterogeneous group with & Amyloidosis \\
\hline various etiologies) & \\
\hline \multirow[t]{2}{*}{ HIV TTP/HUS } & TTP \\
\hline & HUS \\
\hline \multicolumn{2}{|l|}{ Tubulointerstitial disease } \\
\hline Proximal tubular injury & Tenofovir, adefovir, cidofovir, didanosine \\
\hline Chronic tubular injury & $\begin{array}{l}\text { Amphotericin, tenofovir, adefovir, } \\
\text { cidofovir }\end{array}$ \\
\hline Diabetes insipidus & $\begin{array}{l}\text { Amphotericin, tenofovir, didanosine, } \\
\text { abacavir }\end{array}$ \\
\hline Crystal nephropathy & $\begin{array}{l}\text { Indinavir, atazanavir, sulfadiazine, } \\
\text { ciprofloxacin, acyclovir (IV) }\end{array}$ \\
\hline \multirow[t]{7}{*}{ Interstitial nephritis } & Infections (including HIV, BK virus) \\
\hline & Immune reconstitution inflammatory \\
\hline & syndrome following cART \\
\hline & Allergy to $\beta$-lactam, rifampicin, proton \\
\hline & pump inhibitors, allopurinol, phenytoin, \\
\hline & and drugs causing crystal nephropathy \\
\hline & (listed in this table) \\
\hline
\end{tabular}

\section{Comorbid illness}

Diabetic nephropathy

Hypertensive nephrosclerosis

Autoimmune disease (lupus nephritis)

Note: Adapted from Naicker S, Rahmanian S, Kopp JB. HIV and chronic kidney disease. Clin Nephrol. 2015;83(7 Suppl 1):32-38, with permission. ${ }^{137}$ Adapted from Comprehensive Clinical Nephrology. Johnson RJ, Feehally J, Floege J, editors. Human immunodeficiency virus infection and the kidney. Kopp JB, Naicker S. Philadelphia: $\odot$ Elsevier Saunders; 2015. ${ }^{138}$

Abbreviations: CART, combined antiretroviral therapy; FSGS, focal segmental glomerulosclerosis; HIVAN, HIV-associated nephropathy; HIVICD, HIV immune complex disease; HUS, hemolytic uremic syndrome; IV, intravenous; TTP, thrombotic thrombocytopenic purpura.

HIV-associated immune complex disease (HIVICD) occurs predominately in European and Asian populations. ${ }^{39}$ It is a diverse group including immune complex glomerular disease (membranous nephropathy, membranoproliferative, and mesangial proliferative glomerulonephritis), IgA nephropathy, and lupus-like proliferative glomerulonephritis. ${ }^{41-43}$ HIVICD is characterized histologically by immune complex deposits in the capillary loops and mesangium, mesangial cell expansion, and tubulointerstitial inflammation (predominately macrophages, 


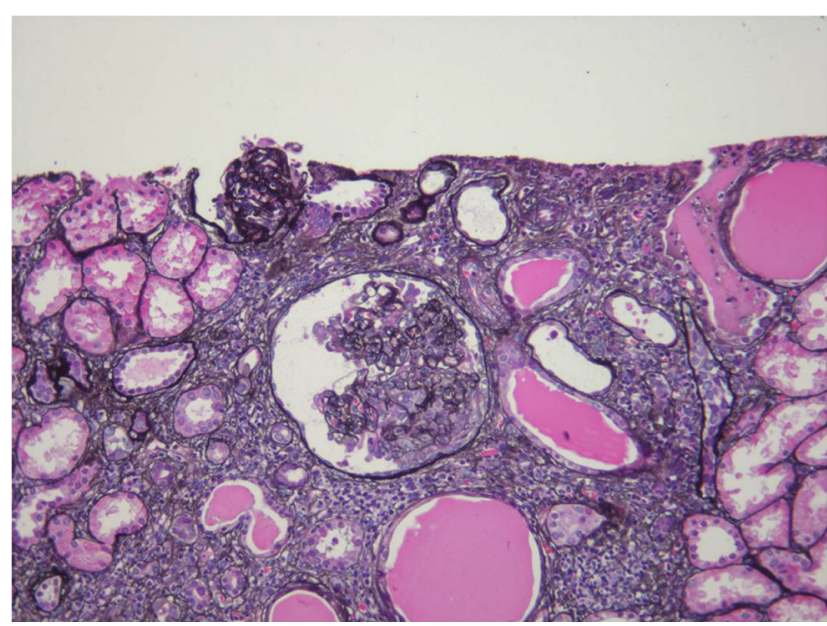

Figure I HIVAN (silver methenamine, $\times 200$ )

Note: Collapsing glomerulopathy with tubular microcysts and interstitial inflammation and scarring (Courtesy of Dr Pulane Mosiane, Department of Anatomical Pathology, University of the Witwatersrand, Johannesburg, South Africa).

Abbreviation: HIVAN, HIV-associated nephropathy.

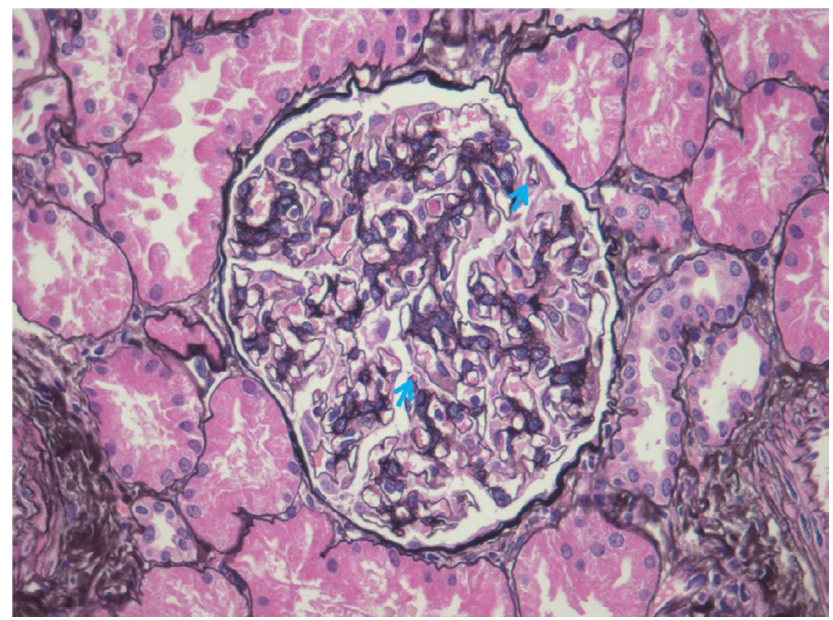

Figure 2 HIVICD (silver methenamine, $\times 400$ ).

Note: Mild mesangial expansion and subepithelial immune complex deposits with a basement membrane reaction (blue arrows) (Courtesy of Dr Pulane Mosiane, Department of Anatomical Pathology, University of the Witwatersrand, Johannesburg, South Africa).

Abbreviation: HIVICD, HIV immune complex disease.

eosinophils, and B cells; Figure 2). ${ }^{41-43}$ Subepithelial immune deposits, described as a "ball-in-cup" basement membrane reaction, are also seen. ${ }^{34}$ The prevalence in African biopsy series is $17 \%-40 \% .^{18,34,35}$ HIVICD has not been extensively studied, and the direct role of HIV infection in its pathogenesis is not known. ${ }^{44,45}$ Booth et al ${ }^{46}$ recently reported on a multicentre study describing the clinical characteristics and outcomes of HIVICD in renal biopsies between 1998 and 2012. Of 265 biopsies, 92 revealed immune complex disease (ICD). They excluded biopsies with features of IgA nephropathy $(n=27)$ and lupus nephritis $(\mathrm{n}=6)$ and classified the remaining ICD as HIVICD $(\mathrm{n}=59)$. Black ethnicity $(P=0.021)$ and HIV viremia $(P=0.0009)$ were associated with the biopsy diagnosis of
HIVICD. Renal outcomes were better in patients with HIVICD than those with IgA nephropathy or HIVAN. Improvement in eGFR and significant reduction in proteinuria were observed in patients with HIVICD who initiated cART, suggesting that this subgroup of patients may benefit from fully suppressive cART. No significant association between HIVICD and hepatitis B/C viral infection was observed in this series.

Individuals coinfected with HIV and hepatitis $\mathrm{C}$ virus (HCV) are at increased risk of developing, or progression of, CKD. ${ }^{47}$ While the histologic patterns of renal disease have not been studied in large populations of coinfected patients, membranoproliferative glomerulonephritis is most common. ${ }^{48}$ The classic clinical associations with cryoglobulinemia and hypocomplementemia are less frequent in coinfected patients. In the cART era in coinfected patients, there has been a decline in immune complex-related glomerulonephritis and an increase in non-collapsing FSGS. ${ }^{49}$

Other more common patterns of HIV-associated renal disease include HIV-associated thrombotic microangiopathy (TMA), HIV-associated comorbidities (HCV infection, diabetes mellitus, and hypertension), and cART nephrotoxicities.

Widespread use of potent cART and the consequent increased lifespan of HIV-positive individuals have led to the appearance of new patterns of HIV-associated kidney disease, reflecting an increasing burden of comorbid disease and nephrotoxicity related to cART use. ${ }^{50,51}$

In resource-rich settings, there has been a plateau in the incidence of ESRD secondary to HIVAN, with an annual incidence of $800-900$ cases in the US..$^{52}$ However, the prevalence of ESRD in HIV-positive individuals has risen, mainly due to increased longevity on cART. ${ }^{52}$ In biopsy series, there has been a shift from a predominance of HIVAN to an increased frequency of non-collapsing FSGS. ${ }^{26,53}$ An individual chronically infected with HIV is now more likely to have CKD due to non-HIVAN kidney disease. With increased survival and continued exposure to cART, a greater number of HIV-positive individuals are developing comorbid CKD risk factors, such as diabetes and hypertension. HIV may have an additive effect in promoting CKD progression in diabetics, ${ }^{54,55}$ possibly as a result of HIV-induced upregulation of inflammation..$^{56}$

In resource-limited settings such as Africa, little data exist on the effect of comorbid disease on the epidemiology of CKD in HIV-positive individuals. Fabian et al ${ }^{18}$ performed a prospective cohort study in HIV-positive South Africans screened for kidney disease. Kidney biopsies were performed before and after initiation of antiretroviral therapy (ART) to assess the clinical and histological response to treatment. This study demonstrated a rapid virological and renal response to cART in HIV-positive individuals with 
histologically documented HIV-associated kidney disease; follow-up biopsies, however, showed a variable histological response to treatment.

\section{Pathogenesis of HIV CKD Viral factors HIV infection of renal cells}

How HIV infection induces chronic kidney injury leading to the pathologic syndrome of HIVAN is not well understood. Direct viral infection of podocytes, renal parenchymal cells particularly the visceral epithelial cells of the glomerulus, and the tubular epithelial cells, resulting in cytopathic effects (including proliferation and apoptosis), are implicated in the pathogenesis of HIVAN. Two main HIV co-receptors, the chemokine receptors $C C R 5$ and $C X C R 4$ that mediate entry of HIV-1 strains into susceptible cells, are not expressed by intrinsic renal cells. ${ }^{57,58}$ Infection of dendritic cells and podocytes and tubular epithelial cells by receptors of the CD209 (DC-SIGN) antigen and lymphocyte antigen 75 (DEC-205), respectively, may have a contributory role. ${ }^{59}$ Release of inflammatory lymphokines or cytokines following HIV infection of lymphocytes and macrophages may promote injury and fibrosis, as demonstrated in circulating and infiltrating leukocytes at sites of tubulointerstitial inflammation. ${ }^{60,61}$

There are two major types of HIV: HIV type 1 and HIV type 2 . HIV-1 is the most common and pathogenic strain of the virus and is subdivided into groups. HIV-1 group $M$ is the most frequent group and is further divided into subtypes. HIV-1 subtypes are unevenly disseminated throughout different geographical locations. ${ }^{62}$ Western Europeans and North Americans are predominantly infected with HIV-1 subtype B. In Africa, there are several different subtypes and recombinant forms of HIV-1. Subtype C predominates in Southern and Eastern Africa, whereas other subtypes and recombinant forms of HIV-1 are found in Western and Central Africa. HIV-2 is found in some areas of Western Africa. The infecting HIV type or subtype may determine the rate of progression of HIV disease. ${ }^{63}$ Thus, different types or subtypes of HIV may result in differences in the replication abilities within the renal reservoir and thus lead to a variety of clinical expressions. ${ }^{63}$

The HIV-1 subtype $\mathrm{C}$ is highly virulent and accounts for up to $98 \%$ of HIV infections in South Africa, with corresponding higher viral loads and lower CD4 cells with the development of HIVAN. ${ }^{64}$ Late initiation of ART in resource-limited settings also has a part to play in predisposing at-risk individuals to HIVAN; studies have shown that effective rollout of ART could reduce the occurrence of HIVAN. ${ }^{65,66}$

\section{Viral proteins}

Studies in transgenic mice expressing viral proteins have suggested that $v p r$ and macrophage-specific expression of HIV proteins may play a role in the evolution of FSGS. ${ }^{67}$ Some suggest that nef may affect the severity of interstitial nephritis, but not the glomerular changes seen in HIVAN. ${ }^{68}$ Podocyte-restricted expressions of vif, nef, tat, vpr, and rev have been shown to induce many of the features of HIVAN in nef: vpr double transgenic mice models. ${ }^{69}$ In HIVAN specimens, apoptosis of renal epithelial cells mediated by caspase activation and Fas upregulation has been seen. ${ }^{70}$

\section{Host factors}

Genetic variations in the apolipoprotein L1 (APOL1) and myosin heavy 9 chain (MYH9) genes have been found to have a strong association with HIV-associated kidney disease in African-Americans. ${ }^{71,72}$

It has been suggested that through activation of cytokine pathways, disease phenotype could affect the host response to viral infection. It has been shown that upregulation of many genes that mediate the inflammatory response in renal epithelial cells such as chemokines, cytokines, and adhesion molecules occurs in patients with HIV-associated kidney disease. A number of such upregulated genes are targets of nuclear factor- $\kappa \mathrm{B}$ and interleukin (IL)-6. Tumor necrosis factor (TNF) and IL-6 expression by tubular and mesangial epithelial cells increase HIV-1 expression by entering monocytes and further driving cytokine production. The part played by inflammatory mediators in the pathogenesis of HIVAN is not yet entirely understood. ${ }^{73}$ Chronic HIV infection is associated with high levels of immunoglobulins. It is suggested that immune complexes circulating in the systemic circulation are deposited in the microvasculature of the kidney, leading to HIVICD. ${ }^{74}$ A recognized feature of HIV infection includes deposition of platelets and thrombi in the vessel wall and endothelial dysfunction caused by abnormalities of the clotting cascade. How HIV affects renal vasculature is important in understanding the pathogenesis of TMA and other HIVassociated renal diseases. The expression of TNF and IL-1 is upregulated in HIV infection of the kidney. This further drives renal inflammation and can contribute to changes in regulation of the clotting cascade. Fas-mediated apoptosis of endothelial cells is triggered by HIV proteins. Downregulation of von Willebrand factor is a primary component of TMA by antibodies against the ADAMTS13 protease. $^{73}$

\section{Genetic susceptibility}

There is a disparity in the occurrence of HIVAN among HIV-positive individuals such that there is an 18- to 50-fold 
increased risk of developing kidney disease among HIVpositive individuals of African descent aged between 20 and 64 years and who have a poorer prognosis than their European descent counterparts, suggesting that genetic factors play a vital role. ${ }^{75}$ Other risk factors include male sex, low CD4 counts, and high viral load.

Genetic susceptibility to HIVAN had originally been attributed to genetic variations within non-muscle $M Y H 9$ and now considered to be due to APOL1. ${ }^{71,72}$

An association has been shown between the APOL1 gene on chromosome 22 (seen in African-Americans) and FSGS and hypertension-attributed ESRD. A subsequent study revealed 17-fold higher odds for FSGS and 29-fold higher risk for HIVAN in those with the APOL1 variant. ${ }^{76}$ A recent South African study showed 89-fold odds for HIVAN in HIV-positive individuals carrying two APOL1 risk alleles. ${ }^{77}$ Untreated $\mathrm{HIV}$-positive patients with the APOL 1 risk allele have a 50\% risk of developing HIVAN. High-risk $A P O L 1$ variants $\mathrm{G} 1$ and $\mathrm{G} 2$ have been strongly associated with HIVAN. The G1 allele (rs73885319) frequency is reported to be $\sim 7.3 \%$ in South Africa, which is much lower than that reported in West Africa, in whom the frequencies are $\sim 50 \%$ for Yoruba and $23.3 \%$ for Igbo or in African-Americans where the G1 frequency is $\sim 20 \%{ }^{76-78}$ HIV-infected individuals of Ethiopian origin who did carry the high-risk $A P O L 1$ genetic variants were reported to not have HIVAN. ${ }^{79}$

It has been postulated that $A P O L 1$ mediates kidney injury via autophagic and apoptosis pathways. ${ }^{80-83}$

There could also be the possibilities of other environmental exposures and nutritional and genetic factors, coupled with other infections, which may modify the effects of APOL1 variants on the kidney.

\section{Management}

\section{Antiretroviral therapy}

Improvement in renal function has been seen after initiation of cART in patients with HIV-associated CKD. In the DART study from Zimbabwe and Uganda, eGFR improved by 1.9-6.0 $\mathrm{mL} / \mathrm{min}$ per $1.73 \mathrm{~m}^{2}$ after $4-5$ years of cART. ${ }^{84}$ Peters et al ${ }^{15}$ also reported a $21 \%$ improvement in median eGFR after 2 years on cART in patients with HIV-associated CKD from Uganda. Improvement in renal function with a median period of cART of 2 years was reported in a Tanzanian study; there was a decrease from $76 \%$ to $29.2 \%$ in the number of patients with eGFR $<90 \mathrm{~mL} / \mathrm{min}$ per $1.73 \mathrm{~m}^{2} .{ }^{85}$

Lescure et $\mathrm{al}^{50}$ documented the change in histological patterns of renal disease in HIV-positive patients since the introduction of cART to France. Non-collapsing forms of FSGS have overtaken HIVAN as the most common glomerular lesion, which were seen in 47\% of biopsies between 2004 and 2007 .

HIVAN is an indicator for the initiation of cART irrespective of CD4 lymphocyte count. ${ }^{86}$ Rapid progression to ESRD is seen in patients with HIVAN, but not in those on cART. ${ }^{87}$ With the increased use of cART, there has been a decline in the incidence of HIVAN and HIV-associated ESRD. ${ }^{19,50,51,88}$ The US Renal Data System reports a $60 \%$ reduction in the risk of HIVAN-associated ESRD after the introduction of cART. ${ }^{89}$ There have also been sporadic case reports of recovery of renal function following initiation of cART. ${ }^{90,91}$ Patients who develop HIVAN despite being on cART are more likely to develop ESRD. ${ }^{87}$

There is inconclusive evidence for initiating cART in HIVICD; it seems appropriate to do so, given the benefits seen in HIV-associated CKD. A study by Szczech et $\mathrm{al}^{39}$ revealed no benefit with cART in patients with HIVICD. However, two South African studies revealed improved renal function with cART in patients with HIVICD. ${ }^{18,37}$ In the series from Cape Town, 16 of 221 biopsies revealed HIVICD. The patients receiving cART over a 3-year period showed stabilization in eGFR and an improvement in proteinuria, but these findings were not statistically significant. Booth et $\mathrm{al}^{46}$ recently reported an observed significant reduction in proteinuria and improvement in eGFR in patients with HIVICD initiated on cART.

The widespread use of cART has resulted in a decline in the incidence of HIV-associated TMA. cART initiation also resulted in clinical remission in these patients. ${ }^{92-94}$

Dose adjustment of cART is necessary in patients on antiretroviral agents eliminated by the kidney (Table 2). ${ }^{86}$ Incorrect dosing has been associated with higher mortality. ${ }^{95}$ Fixed-dose combinations should be avoided once eGFR is $<60 \mathrm{~mL} / \mathrm{min}$ per $1.73 \mathrm{~m}^{2} .{ }^{86}$

\section{Nephrotoxicity of cART}

Specific cART agents have been associated with an increased risk of developing CKD or CKD progression. Two drugs with confirmed potential to cause nephrotoxicity are tenofovir disoproxil fumarate (TDF), a nucleotide reverse transcriptase inhibitor, and indinavir, a protease inhibitor. Both drugs show a strong association between cumulative exposure and development of CKD. ${ }^{96,97}$ Prolonged use of atazanavir, a newer protease inhibitor, has been associated with renal stones and a decline in eGFR, but not proteinuria or CKD. ${ }^{97}$ Wever et $\mathrm{al}^{98}$ observed stabilization or improvement in eGFR in individuals who discontinued TDF with a eGFR of $<60 \mathrm{~mL} / \mathrm{min}$ per $1.73 \mathrm{~m}^{2}$; however, there was incomplete recovery to 
Table 2 Dose adjustments and renal effects of CART in CKD and ESRD

\begin{tabular}{|c|c|c|c|}
\hline CART name & $\begin{array}{l}\text { CKD (adjusted according to } \\
\text { CrCl by eGFR) }\end{array}$ & Dialysis & Renal effect \\
\hline \multicolumn{4}{|c|}{ Nucleoside or nucleotide analogs } \\
\hline Abacavir & No adjustment & $\begin{array}{l}\text { No adjustment } \\
\text { HD: dosing independent of dialysis } \\
\text { sessions }\end{array}$ & $\begin{array}{l}\text { AIN (case report) } \\
\text { Fanconi syndrome (case report) }\end{array}$ \\
\hline $\begin{array}{l}\text { Azidothymidine } \\
\text { (AZT), zidovudine }\end{array}$ & $\begin{array}{l}\mathrm{CrCl} \geq 15 \mathrm{~mL} / \mathrm{min}: \text { no adjustment } \\
\mathrm{CrCl}<15 \mathrm{~mL} / \mathrm{min}: 100 \mathrm{mg} \text { po } \mathrm{q} 6-8 \mathrm{~h}\end{array}$ & $\begin{array}{l}\text { HD: } 100 \mathrm{mg} \text { po } q 6-8 \mathrm{~h} \text { or } 300 \mathrm{mg} \text { po qd } \\
\text { PD: no data }\end{array}$ & None reported \\
\hline Didanosine (ddi) & $\begin{array}{l}\text { Weight }>60 \mathrm{~kg} \\
\mathrm{CrCl} 30-59 \mathrm{~mL} / \mathrm{min}: 200 \mathrm{mg} \text { po qd } \\
\mathrm{CrCl} 10-29 \mathrm{~mL} / \mathrm{min}: 150 \mathrm{mg} \text { po qd } \\
\mathrm{CrCl}<10 \mathrm{~mL} / \mathrm{min}: 75 \mathrm{mg} \text { po qd } \\
\text { Weight }<60 \mathrm{~kg} \\
\mathrm{CrCl} 30-59 \mathrm{~mL} / \mathrm{min}: 150 \mathrm{mg} \text { po qd } \\
\mathrm{CrCl} 10-29 \mathrm{~mL} / \mathrm{min}: 100 \mathrm{mg} \text { po qd } \\
\mathrm{CrCl}<10 \mathrm{~mL} / \mathrm{min}: 75 \mathrm{mg} \text { po qd }\end{array}$ & $\begin{array}{l}\mathrm{HD} \text { : dosing as per } \mathrm{CrCl}<10 \mathrm{~mL} / \mathrm{min} \text {, } \\
\text { dosing after } \mathrm{HD} \text { session } \\
\text { PD: dosing as per } \mathrm{CrCl}<10 \mathrm{~mL} / \mathrm{min}\end{array}$ & $\begin{array}{l}\text { Fanconi Syndrome } \\
\text { AKI } \\
\text { Lactic acidosis } \\
\text { Nephrogenic diabetes insipidus (case } \\
\text { reports) }\end{array}$ \\
\hline Emtricitabine & $\begin{array}{l}\mathrm{CrCl}>50 \mathrm{~mL} / \mathrm{min}: \text { no adjustment } \\
\mathrm{CrCl} 30-49 \mathrm{~mL} / \mathrm{min}: 200 \mathrm{mg} \text { po } \mathrm{q} 48 \mathrm{~h} \\
\mathrm{CrCl} 15-29 \mathrm{~mL} / \mathrm{min}: 200 \mathrm{mg} \text { po } \mathrm{q} 72 \mathrm{~h} \\
\mathrm{CrCl}<15 \mathrm{~mL} / \mathrm{min}: 200 \mathrm{mg} \text { po q } 96 \mathrm{~h}\end{array}$ & $\begin{array}{l}\text { HD: } 200 \text { mg po q96h, dosing after HD } \\
\text { session } \\
\text { PD: no data }\end{array}$ & \\
\hline Lamivudine (3TC) & $\begin{array}{l}\mathrm{CrCl}>50 \mathrm{~mL} / \mathrm{min} \text { : no adjustment } \\
\mathrm{CrCl} 30-49 \mathrm{~mL} / \mathrm{min}: 150 \mathrm{mg} \text { po qd } \\
\mathrm{CrCl} 15-29 \mathrm{~mL} / \mathrm{min}: 150 \mathrm{mg} \text { first dose, } \\
\text { then } 100 \mathrm{mg} \text { po qd } \\
\mathrm{CrCl} 5-14 \mathrm{~mL} / \mathrm{min}: 150 \mathrm{mg} \text { first dose, } \\
\text { then } 50 \mathrm{mg} \text { po qd } \\
\mathrm{CrCl}<5 \mathrm{~mL} / \mathrm{min}: 50 \mathrm{mg} \text { first dose, then } \\
25 \mathrm{mg} \text { po qd }\end{array}$ & $\begin{array}{l}\text { HD: } 50 \mathrm{mg} \text { first dose, then } 25 \mathrm{mg} \text { po } \\
\text { qd, dosing after HD session }\end{array}$ & $\begin{array}{l}\text { Renal tubular acidosis } \\
\text { Hypophosphatemia (case report) }\end{array}$ \\
\hline Stavudine (d4T) & $\begin{array}{l}\mathrm{CrCl}>50 \mathrm{~mL} / \mathrm{min}: \text { no adjustment } \\
\mathrm{CrCl} 26-50 \mathrm{~mL} / \mathrm{min}: 15-20 \mathrm{mg} \text { po bid } \\
\mathrm{CrCl} \leq 25 \mathrm{~mL} / \mathrm{min}: 15-20 \mathrm{mg} \text { po qd }\end{array}$ & $\begin{array}{l}\text { HD: } 20 \text { mg po qd, dosing after HD } \\
\text { session } \\
\text { PD: has been used safely }\end{array}$ & $\begin{array}{l}\text { Renal tubular acidosis } \\
\text { Hypophosphatemia (case report) }\end{array}$ \\
\hline Tenofovir & $\begin{array}{l}\mathrm{CrCl}>50 \mathrm{~mL} / \mathrm{min}: \text { no adjustment } \\
\mathrm{CrCl} 30-49 \mathrm{~mL} / \mathrm{min}: 300 \mathrm{mg} \text { po } \mathrm{q} 48 \mathrm{~h} \\
\mathrm{CrCl} 10-29 \mathrm{~mL} / \mathrm{min}: 300 \mathrm{mg} \text { po } \mathrm{q} 72 \mathrm{~h}\end{array}$ & $\begin{array}{l}300 \text { mg po every } 7 \text { days, dosing after } \\
\text { HD session }\end{array}$ & $\begin{array}{l}\text { Proximal tubular dysfunction with Fanconi } \\
\text { syndrome } \\
\text { Nephrogenic diabetes insipidus } \\
\text { AKI } \\
\text { CKD }\end{array}$ \\
\hline Zalcitabine & $\begin{array}{l}\mathrm{CrCl}>40 \mathrm{~mL} / \mathrm{min}: \text { no adjustment } \\
\mathrm{CrCl} 10-40 \mathrm{~mL} / \mathrm{min}: 0.75 \mathrm{mg} \text { po } \mathrm{q} / 2 \mathrm{~h} \\
\mathrm{CrCl}<10 \mathrm{~mL} / \mathrm{min}: 0.75 \mathrm{mg} \text { po } \mathrm{q} 24 \mathrm{~h}\end{array}$ & $\begin{array}{l}\mathrm{HD} \text { : dosage for } \mathrm{CrCl}<10 \mathrm{~mL} / \mathrm{min} \text {, } \\
\text { dosing after } \mathrm{HD} \text { session } \\
\text { PD: no data }\end{array}$ & \\
\hline $\begin{array}{l}\text { Non-nucleoside } \\
\text { reverse } \\
\text { transcriptase } \\
\text { inhibitors }\end{array}$ & No adjustment & No adjustment & Efavirenz: nephrolithiasis \\
\hline $\begin{array}{l}\text { Protease } \\
\text { inhibitors }\end{array}$ & No adjustment & No adjustment & $\begin{array}{l}\text { Atazanavir: AIN (case report) } \\
\text { Indinavir: AKI (AIN), CKD (AIN), } \\
\text { nephrolithiasis, intratubular drug } \\
\text { precipitation, papillary necrosis, } \\
\text { hypertension, renal atrophy } \\
\text { Nelfinavir: nephrolithiasis (case report) } \\
\text { Ritonavir: AKI } \\
\text { Saquinavir: AKI in association with } \\
\text { ritonavir }\end{array}$ \\
\hline $\begin{array}{l}\text { Entry or fusion } \\
\text { inhibitor }\end{array}$ & & & \\
\hline Enfuvirtide & $\begin{array}{l}\mathrm{CrCl} \geq 35 \mathrm{~mL} / \mathrm{min}: \text { no adjustment } \\
\mathrm{CrCl}<35 \mathrm{~mL} / \mathrm{min}: \text { unknown, use with } \\
\text { caution }\end{array}$ & Unknown, use with caution & $\begin{array}{l}\text { Membranoproliferative } \\
\text { glomerulonephritis (case report) }\end{array}$ \\
\hline
\end{tabular}




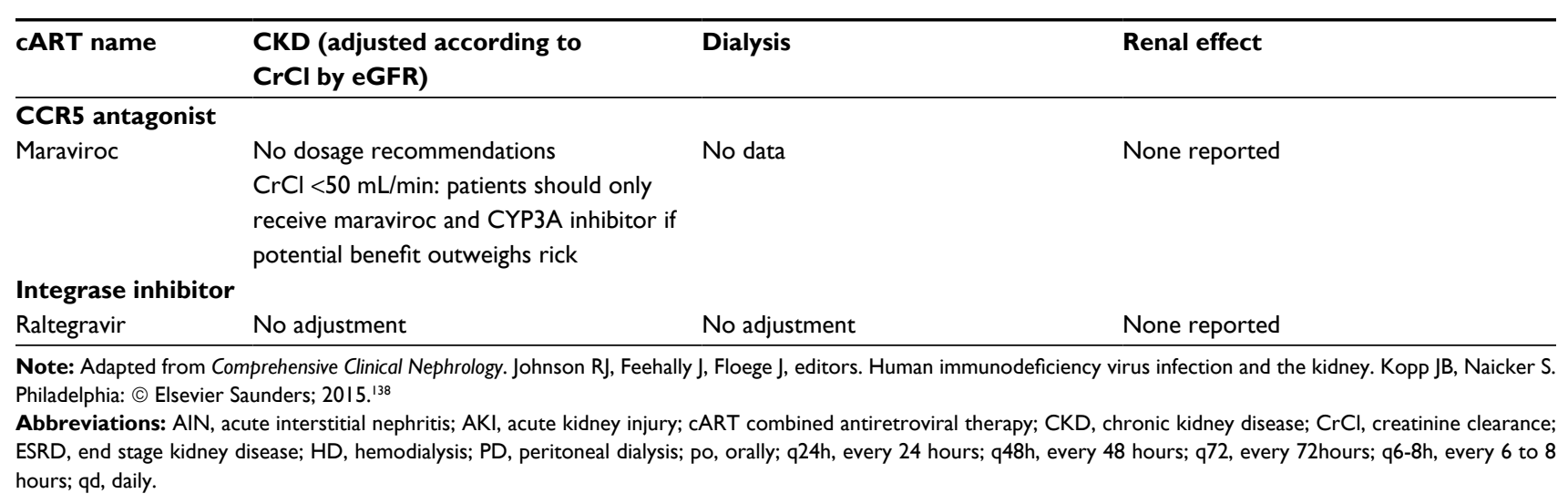

baseline eGFR in more than half of the individuals. The use of a TDF-based cART regimen has been associated with a greater eGFR decline compared with a non-TDF-based regimen; the clinical importance of this association is not known. TDF nephrotoxicity may be enhanced by the coadministration of the following drugs: acyclovir, cidofovir, valacyclovir, ganciclovir, valganciclovir, dipyridamole, nonsteroidal antiinflammatory drugs, probenecid, and ritonavir. ${ }^{99}$

Guidelines recommend the avoidance of TDF if eGFR $<60 \mathrm{~mL} / \mathrm{min}$ per $1.73 \mathrm{~m}^{2}$. In patients already on TDF who experience a $>25 \%$ decline in eGFR from baseline and an eGFR $<60 \mathrm{~mL} / \mathrm{min}$ per $1.73 \mathrm{~m}^{2}$, a substitution to an alternate antiretroviral is recommended.

\section{Angiotensin-converting enzyme inhibitors/angiotensin receptor blockers}

No randomized trials of renin-angiotensin inhibitors in patients with HIV-related CKD have been conducted. Most studies concerning the use of angiotensin-converting enzyme (ACE) inhibitors/angiotensin receptor blockers (ARB) in HIV-positive CKD patients were undertaken in patients with HIVAN in the pre-cART era. ACE inhibitor use was associated with a lower risk of ESRD and longer time to ESRD. ${ }^{100-102}$

In a single-center prospective cohort study by Wei et al, ${ }^{101} 44$ patients with biopsy-proven HIVAN were included. A total of 28 patients received fosinopril $10 \mathrm{mg} /$ day. The study period was 5.1 years. Median renal survival of treated patients was significantly improved after receiving fosinopril. The risk of renal failure was also reduced with ACE inhibitors (relative risk $[R R]=0.003, P<0.0001$ ). Survival was improved in the ACE inhibitor treatment group $(P<0.001)$.

The use of reverse transcriptase inhibitors and captopril was independently associated with a longer mean renal survival before ESRD in 18 cases of biopsy-proven HIVAN before $1996 .{ }^{102}$
Treatment with an ACE inhibitor/ARB is recommended, when clinically indicated in patients with confirmed or suspected HIVAN, or clinically significant albuminuria (in diabetic mellitus patients with $>30 \mathrm{mg}$ albumin/day and nondiabetic patients with $>300 \mathrm{mg}$ albumin/day). ${ }^{86}$

\section{Immunosuppression}

Corticosteroids are not considered to be standard treatment in HIVAN. Retrospective observational studies and uncontrolled trials in the pre-cART era suggested modest, short-lived benefits. Eustace et $\mathrm{al}^{103}$ included 21 patients in a retrospective cohort study, where 13 received corticosteroids (prednisone $60 \mathrm{mg}$ /day for 1 month). At 6 months, one patient from the nonsteroid group and seven patients who received steroids remained dialysis free. In a retrospective cohort of 102 biopsy-confirmed cases of HIVAN from 18 hospitals in France between 1984 and 1996, delay in the initiation of hemodialysis was seen in patients receiving prednisone at $1 \mathrm{mg} / \mathrm{kg}$ for 2-6 weeks $(R R=0.29$ for progression to dialysis with prednisone). ${ }^{104}$ Sothinathan et $\mathrm{al}^{105}$ reported a case study of a single patient whose creatinine remained stable but proteinuria increased after 2 years. There was no associated increase in opportunistic infections but a significant increase in avascular necrosis. ${ }^{106-108}$ Wearne ${ }^{109}$ is currently conducting a prospective randomized control study with the aim of assessing whether corticosteroids preserve/improve renal function and proteinuria or histological features in patients with biopsy-proven HIVAN. Patients receive $1 \mathrm{mg} / \mathrm{kg}$ of prednisone for $1 \mathrm{month}$, and the dose is thereafter tapered by $10 \mathrm{mg} / \mathrm{month}$. Interim data presented at the World Congress of Nephrology 2015 showed promising improvement in eGFR but not proteinuria. Patients receiving steroids had a greater risk of herpes zoster, but mortality was not significantly higher. Corticosteroids are recommended as a possible adjunct to cART and ACE inhibitors/ARB in biopsy-proven HIVAN.$^{86}$ There are no published data of corticosteroid use in renal disease other than HIVAN. 
Data on cyclosporine efficacy in children with HIVAN to reduce proteinuria are limited. ${ }^{110}$

\section{Blood pressure control}

Optimal blood pressure targets have not been specifically evaluated in HIV-positive patients with CKD. The Eighth Joint National Committee guidelines recommend a target blood pressure of $\leq 140 / 90 \mathrm{mmHg}$ for patients with CKD. ${ }^{111}$ KDIGO (Kidney Disease Improving Global Outcomes) 2012 guideline recommends a target blood pressure of $\leq 130 / 80$ mmHg for patients with CKD with moderate to severely increased albuminuria. ${ }^{12}$

Other standard management approaches for patients with CKD are recommended. These include addressing other cardiovascular risk factors (appropriate use of statins and aspirin, weight loss, cessation of smoking), avoidance of nephrotoxins and management of serum bicarbonate and uric acid, anemia, calcium, and phosphate abnormalities.

\section{Vaccinations}

Suboptimal response to vaccinations is likely, due to combined immunosuppression from HIV infection and CKD. The development of protective antibodies and the length of protection are likely to be reduced. ${ }^{113}$ The following vaccines are recommended in HIV-positive patients: influenza, hepatitis $\mathrm{B}$, and pneumococcal. ${ }^{114}$

\section{Renal replacement therapy Dialysis}

With the widespread use of cART, HIV-positive patients are at risk not only of HIV-related kidney disease but also of diseases associated with the aging process, such as hypertension and diabetes mellitus. HIV-positive patients are at increased risk of developing ESRD compared with the general population. ${ }^{115}$ Risk factors for the development of ESRD in HIV-positive patients include traditional risk factors (hypertension, diabetes mellitus, cardiovascular disease) and HIV-associated factors (low CD4 lymphocyte count, high HIV-RNA, coinfection with hepatitis C). ${ }^{23}$

There is no evidence to suggest that either of the dialysis modalities is superior in HIV-positive patients. ${ }^{116}$ Survival rates on dialysis are comparable to those of HIV-negative dialysis patients.

HIV-positive patients on hemodialysis do not require isolation or dedicated machines. ${ }^{117}$ Retrospective data have documented a significant increase in arteriovenous graft thrombosis and infections, which is not seen in patients with native arteriovenous fistulae (AVF). Thus, AVF are the access of choice, and early creation of AVF is recommended in HIV-positive patients approaching dialysis. ${ }^{118-120}$ While transmission of HIV in the dialysis unit is rare, precise use of standard infection control procedures ensures a reduced risk. ${ }^{116}$ Patient-to-patient HIV transmission has been documented in dialysis units in Argentina, Colombia, and Egypt. ${ }^{121-123}$ Dialyzer reuse by the same patient is not associated with increased risk of transmission to staff members. ${ }^{117}$

HIV survives in peritoneal dialysis drainage fluid and dry tubing and thus should be disposed of correctly. ${ }^{124,125}$ Dilutions of $50 \%$ Amikacin and $10 \%$ bleach are able to inactivate HIV in dialysate. ${ }^{124}$ Variable rates of peritonitis have been reported. Some studies have reported increased incidence of pseudomonas and fungal peritonitis in HIV-positive peritoneal dialysis patients. ${ }^{126,127}$ Other studies show rates of peritonitis comparable with HIV-negative peritoneal dialysis patients. ${ }^{128,129}$

Improved survival of HIV-positive patients on dialysis is seen with younger age, higher CD4 counts, cART use, and initiation of RRT at an earlier stage of HIV infection. ${ }^{129-132}$ There is an increased risk of cardiovascular disease in HIVpositive dialysis patients on long-term cART.

\section{Renal transplantation}

With the use of cART, HIV infection is no longer a contraindication to renal transplantation. ${ }^{133}$ Stock et al ${ }^{134}$ reported on a series of 150 renal transplants occurring between 2003 and 2009. Although there are higher rates of acute graft rejection in HIV-positive recipients, graft and patient survival rates are comparable to HIV-negative recipients. Outcomes of HIV-positive to HIV-positive kidney transplantation has been reported by Muller et al. ${ }^{135,136} \mathrm{~A}$ total of 27 HIV-positive patients received a cadaveric kidney from HIV-positive donors. Cumulative rates of graft survival, $93 \%$ at 1 year and $84 \%$ at 5 years, and cumulative rates of patient survival, $84 \%$ at 1 year and $74 \%$ at 5 years, are similar to outcomes reported in HIV-positive patients who received a graft from HIV-negative donors. There is a risk of HIVAN recurrence in the allograft.

Pharmacological interactions occur between antiretroviral agents and transplant medications. Dose adjustment and immunosuppressant drug monitoring is recommended. ${ }^{86}$

\section{Screening and early diagnosis of HIV CKD}

HIV-positive individuals present with advanced stages of CKD in clinical practice in Africa. Early diagnosis of kidney disease by screening of HIV-positive individuals for the presence of kidney disease is critical for the optimal management of these patients. The HIV Medicine Association of the Infectious 
Disease Society of North America recommends screening for the presence of kidney disease upon detection of HIV infection and annually thereafter in high-risk populations, similar to the recommendations for type 2 diabetes mellitus. ${ }^{75,86}$ Screening strategies include measurement of blood pressure, kidney function (serum creatinine; eGFR), and urine examination (proteinuria via spot urine protein creatinine ratios; hematuria). Referral to nephrology services is recommended when the eGFR is $<60 \mathrm{~mL}$ per $1.73 \mathrm{~m}^{2}$ or if it decreases by $>25 \%$ from baseline. The role of kidney biopsy has been debated; there are no clear clinical diagnostic criteria for HIVAN; the decision for a kidney biopsy should be guided by the risks to the individual patient, the uncertainty of diagnosis, and the patient's preference.

\section{Conclusion}

The presence of advanced HIV-associated CKD is an important cause of mortality and morbidity. The recent World Health Organization recommendations to treat all individuals upon diagnosis of HIV infection, while causing huge concerns for overburdened health systems and constrained health budgets, may decrease the burden of HIV CKD. Screening and early diagnosis of kidney disease will improve outcomes in patients with HIV infection.

\section{Disclosure}

The authors report no conflicts of interest in this work.

\section{References}

1. World Health Organisation. WHO Factsheet; 2015. Available from: http://www.who.int/hiv/en/. Accessed August 16, 2016.

2. Mocroft A, Kirk O, Gatell J, et al. Chronic renal failure among HIV1-infected patients. AIDS. 2007;21(9):1119-1127.

3. Sorli ML, Guelar A, Montero M, Gonzalez A, Rodriguez E, Knobel $\mathrm{H}$. Chronic kidney disease prevalence and risk factors among HIV infected patients. J Acquir Immune Defic Syndr. 2008;48(4): 506-508.

4. Fernando SK, Finkelstein FO, Moore BA, Weissman S. Prevalence of chronic kidney disease in an urban HIV infected population. Am J Med Sci. 2008;335(2):89-94.

5. Yanik EL, Lucas GM, Vlahov D, Kirk GD, Mehta SH. HIV and proteinuria in an injection drug user population. Clin J Am Soc Nephrol. 2010;5(10):1836-1843.

6. Szczech LA, Grunfeld C, Scherzer R, et al. Microalbuminuria in HIV infection. AIDS. 2007;21(8):1003-1009.

7. Wyatt CM, Winston JA, Malvestutto CD, et al. Chronic kidney disease in HIV infection: an urban epidemic. AIDS. 2007;21(15):2101-2103.

8. Cheung CY, Wong KM, Lee MP, et al. Prevalence of chronic kidney disease in Chinese HIV-infected patients. Nephrol Dial Transplant. 2007;22(11):3186-3190.

9. Jevtović DJ, Dragović G, Salemović D, Ranin J, Djurković-Djaković $\mathrm{O}$. The metabolic syndrome, an epidemic among HIV-infected patients on HAART. Biomed Pharmacother. 2008;63(5):337-342.

10. Ramezani A, Mohraz M, Banifazl M, et al. Frequency and associated factors of proteinuria an Iranian HIV-positive patients. Int J Infect Dis. 2008;12(5):490-494.
11. Cavalcante MA, Coelho SN, Lacerda HR. Prevalence of persistent proteinuria in stable HIV/AIDS patients and its association with HIV nephropathy. Braz J Infect Dis. 2007;11(5):456-461.

12. Emem CP, Arogundade F, Sanusi A, et al. Renal disease in HIV-seropositive patients in Nigeria: an assessment of prevalence, clinical features and risk factors. Nephrol Dial Transplant. 2008;23(2):741-746.

13. Mulenga LB, Kruse G, Lakhi S, et al. Baseline renal insufficiency and risk of death among HIV-infected adults on antiretroviral therapy in Lusaka, Zambia. AIDS. 2008;22(14):1821-1827.

14. Mortier E, Toure S, Seyler C, et al. Urinary pH in HIV-infected adults in Ivory Coast and in France. AIDS. 2003;17(13):2003-2005.

15. Peters PJ, Moore DM, Mermin J, et al. Antiretroviral therapy improves renal function among HIV-infected Ugandans. Kidney Int. 2008; 74(7):925-929.

16. Wools-Kaloustian K, Gupta SK, Muloma E, et al. Renal disease in antiretroviral-naïve HIV-infected outpatient population in Western Kenya. Nephrol Dial Transplant. 2007;22(8):2208-2212.

17. Han TM, Naicker S, Ramdial PK, Assounga AG. A cross-sectional study of HIV-seropositive patients with varying degrees of proteinuria in South Africa. Kidney Int. 2006;69(12):2243-2250.

18. Fabian J, Naicker S, Goetsch S, Venter WD. The clinical and histological response of HIV-associated kidney disease to antiretroviral therapy in South Africans. Nephrol Dial Transplant. 2013;28(6):1543-1554.

19. Abraham AG, Althoff KN, Jing Y, et al. End-stage renal disease among HIV-infected adults in North America. Clin Infect Dis. 2015; 15(60):941-949.

20. Lucas GM, Mehta SH, Atta MG, et al. End-stage renal disease and chronic kidney disease in a cohort of African-American HIV-infected and at-risk HIV-seronegative participants followed between 1988 and 2004. AIDS. 2007;21(18):2435-2443.

21. Bansi L, Hughes A, Bhagani S, et al; UK CHIC/ESRF study group. Clinical epidemiology of HIV-associated end-stage renal failure in the UK. AIDS. 2009;23(18):2517-2521.

22. Bickel M, Marben W, Betz C, et al. End-stage renal disease and dialysis in HIV-positive patients: observations from a long-term cohort study with a follow-up of 22 years. HIV Med. 2013;14(3):127-135.

23. Jotwani V, Li Y, Grunfeld C, Choi AI, Shlipak MG. Risk factors for ESRD in HIV-infected individuals: traditional and HIV-related factors. Am J Kidney Dis. 2012;59(5):628-635.

24. Lucas GM, Lau B, Atta MG, Fine DM, Keruly J, Moore RD. Chronic kidney disease incidence, and progression to end-stage renal disease, in HIV-infected individuals: a tale of two races. $J$ Infect Dis. 2008; 197(11):1548-1557.

25. Rao TK. Clinical features of human immunodeficiency virus associated nephropathy. Kidney Int Suppl. 1991;35:S13-S18.

26. Berliner AR, Fine DM, Lucas GM, et al. Observations on a cohort of HIV-infected patients undergoing native renal biopsy. Am J Nephrol. 2008;28(3):478-486.

27. Wyatt CM, Klotman PE, D'Agati VD. HIV-associated nephropathy: clinical presentation, pathology, and epidemiology in the era of antiretroviral therapy. Semin Nephrol. 2008;28(6):513-522.

28. Pardo V,Aldana M, Colton RM, et al. Glomerular lesions in the acquired immunodeficiency syndrome. Ann Intern Med. 1984;101(4):429-434

29. Rao TK, Filippone EJ, Nicastri AD, et al. Associated focal and segmental glomerulosclerosis in the acquired immunodeficiency syndrome. N Engl J Med. 1984;310(11):669-673.

30. D’Agati V, Suh JI, Carbone L, Cheng JT, Appel G. Pathology of HIV associated nephropathy: a detailed morphologic and comparative study. Kidney Int. 1989;35(6):1358-1370.

31. Bourgoignie JJ, Pardo V. The nephropathology in human immunodeficiency virus (HIV-1) infection. Kidney Int Suppl. 1991;35: S19-S23.

32. Rey L, Viciana A, Ruiz P. Immunopathological characteristics of in situ T-cell subpopulations in human immunodeficiency virus-associated nephropathy. Hum Pathol. 1995;26(4):408-415.

33. Kopp JB, Smith MW, Nelson GW, et al. MYH9 is a major-effect risk gene for focal segmental glomerulosclerosis. Nat Genet. 2008;40(10): 1185-1192. 
34. Gerntholtz TE, Goetsch SJ, Katz I. HIV-associated nephropathy: a South African perspective. Kidney Int. 2006;69(10):1185-1191.

35. Diana N, Davies M, Naicker S, et al. Clinicopathological correlation of renal disease in HIV infection. In: Abstracts of the World Congress of Nephrology; 2013: p.18. Hong Kong.

36. Swanepoel CR, Okpechi I. HIV and renal disease in Africa: the journey so far and future directions. Port J Nephrol Hypert. 2011;25: $11-15$.

37. Wearne N, Swanepoel CR, Boulle A, Duffield MS, Rayner BL. The spectrum of renal histologies seen in HIV with outcomes, prognostic indicators and clinical correlations. Nephrol Dial Transplant. 2012; 27(11):4109-4118

38. Lucas GM, Eustace JA, Sozio S, Mentari EK, Appiah KA, Moore RD. Highly active antiretroviral therapy and the incidence of HIV-1-associated nephropathy: a 12-year cohort study. AIDS. 2004;18(3):541-546.

39. Szczech LA, Gupta SK, Habash R, et al. The clinical epidemiology and course of the spectrum of renal diseases associated with HIV infection. Kidney Int. 2004;66(3):1145-1152.

40. Wyatt CM. The kidney in HIV infection: beyond HIV-associated nephropathy. Top Antivir Med. 2012;20(3):106-110.

41. Kimmel PL, Phillips TM, Ferreira-Centeno A, et al. Brief report: idiotypic IgA nephropathy in patients with human immunodeficiency virus infection. N Engl J Med. 1992;327(10):702-706.

42. Cohen SD, Kimmel PL. Immune complex renal disease and human immunodeficiency virus infection. Semin Nephrol. 2008;28(6): 535-544.

43. Haas M, Kaul S, Eustace JA. HIV-associated immune complex glomerulonephritis with "lupus-like" features: a clinicopathologic study of 14 cases. Kidney Int. 2005;67(4):1381-1390.

44. Kimmel PL, Phillips TM, Ferreira-Centeno A, Farkas-Szallasi T, Abraham AA, Garrett CT. HIV-associated immune-mediated renal disease. Kidney Int. 1993;44(6):1327-1340.

45. Katz A, Bargman JM, Miller DC, Guo JW, Ghali VS, Schoeneman MJ. IgA nephritis in HIV-positive patients: a new HIV-associated nephropathy? Clin Nephrol. 1992;38(2):61-68.

46. Booth JW, Hamzah L, Jose S, et al. Clinical characteristics and outcomes of HIV-associated immune complex kidney disease. Nephrol Dial Transplant. Epub 2016 Jan 18.

47. Wyatt CM, Malvestutto C, Coca SG, et al. The impact of hepatitis co-infection on HIV-related kidney disease: a systematic review and meta-analysis. AIDS. 2008;22(14):1799-1807.

48. Stokes MB, Chawla H, Brody RI, et al. Immune complex glomerulonephritis in patients coinfected with human immunodeficiency virus and hepatitis C virus. Am J Kidney Dis. 1997;29(4):514-525.

49. Mohan S, Herlitz LC, Tan J, et al. The changing pattern of glomerular disease in HIV and Hepatitis $\mathrm{C}$ co-infected patients in the era of HAART. Clin Nephrol. 2013;79(4):285-291.

50. Lescure FX, Flateau C, Pacanowski J, et al. HIV-associated kidney glomerular diseases: changes with time and HAART. Nephrol Dial Transplant. 2012;27(6):2349-2355.

51. Mallipattu S, Salem F, Wyatt C. The changing epidemiology of HIVrelated chronic kidney disease in the era of antiretroviral therapy. Kidney Int. 2014;86(2):259-265.

52. United States Renal Data System (USRDS) [webpage on the Internet]. 2011 Annual Data Report: Atlas of Chronic Kidney Disease and EndStage Renal Disease in the United States; 2011. Available from: www. usrds.org/atlas11.aspx. Accessed May 2016.

53. Wyatt CM, Morgello S, Katz-Malamed R, et al. The spectrum of kidney disease in patients with AIDS in the era of antiretroviral therapy. Kidney Int. 2009;75(4):428-434.

54. Medapalli RK, Parikh CR, Gordon K, et al. Comorbid diabetes and the risk of progressive chronic kidney disease in HIV-infected adults: data from the Veterans Aging Cohort Study. J Acquir Immune Defic Syndr. 2012;60(4):393-399.

55. Choi AI, Rodriguez RA, Bacchetti P, Bertenthal D, Volberding PA, O'Hare AM. Racial differences in end-stage renal disease rates in HIV infection versus diabetes. J Am Soc Nephrol. 2007;18(11): 2968-2974.
56. Mallipattu SK, Liu R, Zhong Y, et al. Expression of HIV transgene aggravates kidney injury in diabetic mice. Kidney Int. 2013;83(4): 626-634.

57. Eitner F, Cui Y, Hudkins KL, et al. Chemokine receptor CCR5 and CXCR4 expression in HIV-associated kidney disease. JAm Soc Nephrol. 2000;11(5):856-867.

58. Eitner F, Cui Y, Hudkins KL, et al. Chemokine receptor (CCR5) expression in human kidneys and in the HIV infected macaque. Kidney Int. 1998;54(6): 1945-1954.

59. Hatsukari I, Singh P, Hitosugi N, et al. DEC-205-mediated internalization of HIV-1 results in the establishment of silent infection in renal tubular cells. J Am Soc Nephrol. 2007;18(3):780-787.

60. Ross M, Fan C, Ross M, et al. HIV-1 infection initiates an inflammatory cascade in human renal tubular epithelial cells. J Acquir Immune Defic Syndr. 2006;42(1):1-11.

61. Kopp JB, Winkler C. HIV-associated nephropathy in African Americans. Kidney Int Suppl. 2003;83:S43-S49.

62. Hemelaar J, Gouws E, Ghys PD, Osmanov S; WHO-UNAIDS Network for HIV Isolation and Characterisation. Global trends in molecular epidemiology of HIV-1 during 2000-2007. AIDS. 2011;25(5):679-689.

63. Taylor BS, Sobieszczyk ME, McCutchan FE, Hammer SM. The challenge of HIV-1 subtype diversity. $N$ Engl J Med. 2008;358(15): 1590-1602.

64. Novitsky V, Ndung'u T, Wang R, et al. Extended high viremics: a substantial fraction of individuals maintain high plasma viral RNA levels after acute HIV-1 subtype C infection. AIDS. 2011;25(12):1515-1522.

65. Hays T, Wyatt CM. APOL1 variants in HIV-associated nephropathy: just one piece of the puzzle. Kidney Int. 2012;82(3):259-260.

66. Kalayjian RC. The treatment of HIV-associated nephropathy. $A d v$ Chronic Kidney Dis. 2010;17(1):59-71.

67. Snyder A, Alsauskas Z, Gong P, et al. FAT10: a novel mediator of Vpr-induced apoptosis in human immunodeficiency virus-associated nephropathy. J Virol. 2009;83(22):11983-11988.

68. Kajiyama W, Kopp J, Marinos N, Klotman P, Dickie P. Glomerulosclerosis and viral gene expression in HIV-transgenic mice: role of nef. Kidney Int. 2000;58(3):1148-1159.

69. Zuo Y, Matsusaka T, Zhong J, et al. HIV-1 genes vpr and nef synergistically damage podocytes, leading to glomerulosclerosis. J Am Soc Nephrol. 2006;17(10):2832-2843.

70. Conaldi P, Biancone L, Bottelli A, et al. HIV-1 kills renal tubular epithelial cells in vitro by triggering an apoptotic pathway involving caspase activation and Fas upregulation. J Clin Invest. 1998;102(12):2041-2049.

71. Kopp JB, Smith MW, Nelson GW. MYH9 is a major-effect risk gene for focal segmental glomerulosclerosis. Nat Genet. 2008;40(10):1175-1184.

72. Genovese G, Friedman DJ, Ross MD, et al. Association of trypanolytic ApoL1 variants with kidney disease in African Americans. Science. 2010; 329(5993):841-845.

73. Weiner N, Goodman J, Kimmel P. The HIV-associated renal diseases: current insight into pathogenesis and treatment. Kidney Int. 2003;63(5):1618-1631.

74. Kimmel PL, Phillips TM. Immune complex glomerulonephritis associated with HIV infection. In: Kimmel PL, Berns JS, Stein JH, editors. Renal and Urologic Aspects of HIV Infection. New York: Churchill Livingstone; 1995:77-110.

75. Gupta SK, Eustace JA, Winston JA, et al. Guidelines for the management of chronic kidney disease in HIV-infected patients: recommendations of the HIV Medicine Association of the Infectious Diseases Society of America. Clin Infect Dis. 2005;40(11):1559-1585.

76. Kopp JB, Nelson GW, Sampath K, et al. APOL1 genetic variants in focal segmental glomerulosclerosis and HIV-associated nephropathy. J Am Soc Nephrol. 2011;22(11):2129-2137.

77. Kasembeli AN, Duarte R, Ramsay M, et al. APOL1 risk variants are strongly associated with HIV-associated nephropathy in black South Africans. J Am Soc Nephrol. 2015;26(11):2882-2890.

78. Ulasi II, Tzur S, Wasser WG, et al. High population frequencies of APOL1 risk variants are associated with increased prevalence of non-diabetic chronic kidney disease in the Igbo people from south-eastern Nigeria. Nephron Clin Pract. 2013;123(1-2):123-128. 
79. Behar DM, Kedem E, Rosset S, et al. Absence of APOL1 risk variants protects against HIV-associated nephropathy in the Ethiopian population. Am J Nephrol. 2011;34(5):452-459.

80. Smith EE, Malik HS. The apolipoprotein L family of programmed cell death and immunity genes rapidly evolved in primates at discrete sites of host-pathogen interactions. Genome Res. 2009;19(5):850-858.

81. Zhaorigetu S, Wan G, Kaini R, Jiang Z, Hu CA. ApoL1, a BH3-only lipidbinding protein, induces autophagic cell death. Autophagy. 2008;4(8): 1079-1082.

82. Wan G, Zhaorigetu S, Liu Z, Kaini R, Jiang Z, Hu CA. Apolipoprotein L1, a novel Bcl-2 homology domain 3-only lipid-binding protein, induces autophagic cell death. J Biol Chem. 2008;283(31):21540-21549.

83. Perez-Morga D, Vanhollebeke B, Paturiaux-Hanocq F, et al. Apolipoprotein L-I promotes trypanosome lysis by forming pores in lysosomal membranes. Science. 2005;309(5733):469-472.

84. Stöhr WI, Reid A, Walker AS, et al. Glomerular dysfunction and associated risk factors over 4-5 years following antiretroviral therapy initiation in Africa. Antivir Ther. 2011;16(7):1011-1020.

85. Mpondo BC, Kalluvya SE, Peck RN, et al. Impact of antiretroviral therapy on renal function among HIV-infected Tanzanian adults: a retrospective cohort study. PLoS One. 2014;26(9):e89573.

86. Lucas GM, Ross MJ, Stock PG, et al; HIV Medicine Association of the Infectious Diseases Society of America. Clinical practice guideline for the management of chronic kidney disease in patients infected with HIV: 2014 update by the HIV Medicine Association of the Infectious Diseases Society of America. Clin Infect Dis. 2014;59(9):e96-e138.

87. Bigé N, Lanternier F, Viard JP, et al. HIV-associated kidney glomerular diseases: changes with time and HAART. Nephrol Dial Transplant. 2012;27(6):1114-1121

88. Bohmart A, Burns G. Renal disease in an urban HIV population in the era prior and following the introduction of highly active antiretroviral therapy. J Natl Med Assoc. 2011;103(6):513-517.

89. US Renal Data System. USRDS Annual Data Report: Atlas of Chronic Kidney Disease and End-Stage Renal Disease in the United States; 2012. Available from: http://www.usrds.org/atlas12.aspx. Accessed April 2016.

90. Kirchner JT. Resolution of renal failure after initiation of HAART: 3 cases and a discussion of the literature. AIDS Read. 2002;12(3): 103-105.

91. Scheurer D. Rapid reversal of renal failure after initiation of HAART: a case report. AIDS Read. 2004;14(8):443-447.

92. Becker S, Fusco G, Fusco J, et al. HIV-associated thrombotic microangiopathy in the era of highly active antiretroviral therapy: an observational study. Clin Infect Dis. 2004;39(suppl 5):S267.

93. Gervasoni CI, Ridolfo AL, Vaccarezza M, et al. Thrombotic microangiopathy in patients with acquired immunodeficiency syndrome before and during the era of introduction of highly active antiretroviral therapy. Clin Infect Dis. 2002;35(12):1534-1540.

94. Miller RFI, Scully M, Cohen H, et al. Thrombotic thrombocytopaenic purpura in HIV-infected patients. Int J STD AIDS. 2005;16(8):538-542.

95. Tourret J, Tostivint I, Du Montcel ST, et al. Antiretroviral drug dosing errors in HIV-infected patients undergoing hemodialysis. Clin Infect Dis. 2007;45(6):779-784.

96. Mocroft A, Kirk O, Reiss P, et al. Estimated glomerular filtration rate, chronic kidney disease and antiretroviral drug use in HIV-positive patients. AIDS. 2010;24(11):1667-1678.

97. Scherzer R, Estrella M, Li Y, et al. Association of tenofovir exposure with kidney disease risk in HIV infection. AIDS. 2012;26(7): $867-875$.

98. Wever K, van Agtmael MA, Carr A. Incomplete reversibility of tenofovir related renal toxicity in HIV-infected men. J Acquir Immune Defic Syndr. 2010;55(1):78-81.

99. Fernandez-Fernandez B, Montoya-Ferrer A, Sanz AB, et al. Tenofovir nephrotoxicity: 2011 update. AIDS Res Treat. 2011;2011:354908.

100. Burns GC, Paul SK, Toth IR, Sivak SL. Effect of angiotensin-converting enzyme inhibition in $\mathrm{HIV}$-associated nephropathy. J Am Soc Nephrol. 1997;8(7):1140-1146.
101. Wei A, Burns GC, Williams BA, Mohammed NB, Visintainer P, Sivak SL Long-term renal survival in HIV-associated nephropathy with angiotensin-converting enzyme inhibition. Kidney Int. 2003;64(4): 1462-1471

102. Kimmel PL, Mishkin GJ, Umana WO. Captopril and renal survival in patients with human immunodeficiency virus nephropathy. Am J Kidney Dis. 1996;28(2):202-208.

103. Eustace JA, Nuermberger E, Choi M, Scheel PJ Jr, Moore R, Briggs WA. Cohort study of the treatment of severe HIV-associated nephropathy with corticosteroids. Kidney Int. 2000;58(3):1253-1260.

104. Laradi A, Mallet A, Beaufils H, et al. HIV-associated nephropathy: outcome and prognosis factors. J Am Soc Nephrol. 1998;9(12): 2327-2335.

105. Sothinathan R, Briggs WA, Eustace JA. Treatment of HIV-associated nephropathy. AIDS Patient Care STDS. 2001;15(7):363-371.

106. Scribner AN, Troia-Cancio PV, Cox BA, et al. Osteonecrosis in HIV: a case-control study. J Acquir Immune Defic Syndr. 2000;25(1):19-25.

107. Miller KD, Masur H, Jones EC, et al. High prevalence of osteonecrosis of the femoral head in HIV-infected adults. Ann Intern Med. 2002;137(1):17-25.

108. Glesby MJ, Hoover DR, Vaamonde CM. Osteonecrosis in patients infected with human immunodeficiency virus: a case-control study. J Infect Dis. 2001;184(4):519-523.

109. Wearne N. The use of corticosteroids to treat HIV-associated nephropathy in patients on antiretroviral therapy: a randomized controlled trial an interim analysis. In: Abstracts of the World Congress of Nephrology; 2015. Cape Town.

110. Ingulli E, Tejani A, Fikrig S, Nicastri A, Chen CK, Pomrantz A. Nephrotic syndrome associated with acquired immunodeficiency syndrome in children. J Pediatr. 1991;119(5):710-716.

111. James PA, Oparil S, Carter BL. 2014 evidence-based guideline for the management of high blood pressure in adults. Report from the panel members appointed to the eighth joint national committee (JNC 8). JAMA. 2014;311(5):507-520.

112. Levin A, Stevens PE. Summary of KDIGO 2012 CKD Guideline: behind the scenes, need for guidance, and a framework for moving forward. Kidney Int. 2014;85(1):49-61.

113. Linnemann CC Jr, First MR, Schiffman G. Revaccination of renal transplant and hemodialysis recipients with pneumococcal vaccine. Arch Intern Med. 1986;146(8):1554-1556.

114. Panel on Opportunistic Infections in HIV-Infected Adults and Adolescents [webpage on the Internet]. Guidelines for the Prevention and Treatment of Opportunistic Infections in HIV-Infected Adults and Adolescents: Recommendations from the Centers for Disease Control and Prevention, the National Institutes of Health, and the HIV Medicine Association of the Infectious Diseases Society of America. Available from: http://aidsinfo.nih.gov/contentfiles/lvguidelines/adult_oi.pdf. Accessed April 2015.

115. Rasch MG, Helleberg M, Feldt-Rasmussen B, et al. Increased risk of dialysis and end-stage renal disease among HIV patients in Denmark compared with the background population. Nephrol Dial Transplant. 2014;29(6):1232-1238.

116. Ahuja TS, Collinge N, Grady J, Khan S. Is dialysis modality a factor in survival of patients with ESRD and HIV-associated nephropathy? Am J Kidney Dis. 2003;41(5):1060-1064.

117. Recommendations for preventing transmission of infections among chronic hemodialysis patients. MMWR Recomm Rep. 2001;50(RR-5): $1-43$.

118. Curi MA, Pappas PJ, Silva MB Jr, et al. Hemodialysis access: influence of the human immunodeficiency virus on patency and infection rates. J Vasc Surg. 1999;29(4):608-616.

119. Mitchell D, Krishnasami Z, Young CJ, Allon M. Arteriovenous access outcomes in haemodialysis patients with HIV infection. Nephrol Dial Transplant. 2007;22(2):465-470.

120. Fokou M, Teyang A, Ashuntantang G, et al. Complications of arteriovenous fistula for hemodialysis: an 8-year study. Ann Vasc Surg. 2012; 26(5):680-684 
121. Dyer E. Argentinian doctors accused of spreading AIDS. $B M J$. 1993;307(6904):584.

122. Velandia M, Fridkin SK, Cárdenas V, et al. Transmission of HIV in dialysis centre. Lancet. 1995;345(8962):1417.

123. El Sayed NM, Gomatos PJ, Beck-Sagué CM, et al. Epidemic transmission of human immunodeficiency virus in renal dialysis centers in Egypt. J Infect Dis. 2000;181(1):91-97.

124. Farzadegan H, Ford D, Malan M, Masters B, Scheel PJ Jr. HIV-1 survival kinetics in peritoneal dialysis effluent. Kidney Int. 1996;50(5): $1659-1662$.

125. Breyer JA, Harbison MA. Isolation of human immunodeficiency virus from peritoneal dialysate. Am J Kidney Dis. 1993;21(1):23-25.

126. Dressler R, Peters AT, Lynn RI. Pseudomonal and candidal peritonitis as a complication of continuous ambulatory peritoneal dialysis in human immunodeficiency virus-infected patients. Am J Med. 1989;86(6 Pt 2): 787-790.

127. Lewis M, Gorban-Brennan NL, Kliger A, et al. Incidence and spectrum of organisms causing peritonitis in HIV positive patients on CAPD. Adv Perit Dial. 1990;6:136-138.

128. Wasser WG, Boyle MJ, Brandon S, et al. HIV positivity does not predispose peritoneal dialysis patients to peritonitis. J Am Soc Nephrol. 1991;2:369.

129. Kimmel PL, Umana WO, Simmens SJ, Watson J, Bosch JP. Continuous ambulatory peritoneal dialysis and survival of HIV infected patients with end-stage renal disease. Kidney Int. 1993;44(2):373-378.
130. Ortiz C, Meneses R, Jaffe D, Fernandez JA, Perez G, Bourgoignie JJ. Outcome of patients with human immunodeficiency virus on maintenance hemodialysis. Kidney Int. 1988;34(2):248-253.

131. Perinbasekar S, Brod-Miller C, Pal S, Mattana J. Predictors of survival in HIV-infected patients on hemodialysis. Am J Nephrol. 1996;16(4): 280-286.

132. Ahuja TS, Borucki M, Grady J. Highly active antiretroviral therapy improves survival of HIV-infected hemodialysis patients. Am J Kidney Dis. 2000;36(3):574-580.

133. Halpern SDI, Ubel PA, Caplan AL. Solid-organ transplantation in HIV-infected patients. $N$ Engl J Med. 2002;347(4):284-287.

134. Stock PG, Barin B, Murphy B, et al. Outcomes of kidney transplantation in HIV-infected recipients. N Engl J Med. 2010;363(21): 2004-2014.

135. Muller E, Kahn D, Mendelson M. Renal transplantation between HIV-positive donors and recipients. N Engl J Med. 2010;362(24): 2336-2337.

136. Muller E, Barday Z, Mendelson M, Kahn D. HIV-positive-to-HIVpositive kidney transplantation - results at 3 to 5 years. $N$ Engl J Med. 2015;372(7):613-620.

137. Naicker S, Rahmanian S, Kopp JB. HIV and chronic kidney disease. Clin Nephrol. 2015;83(7 Suppl 1):32-38.

138. Kopp JB, Naicker S. Human immunodeficiency virus infection and the kidney. In: Johnson RJ, Feehally J, Floege J, editors. Comprehensive Clinical Nephrology. Philadelphia: Elsevier Saunders; 2015.

\section{Publish your work in this journal}

The International Journal of Nephrology and Renovascular Disease is an international, peer-reviewed open access journal focusing on the pathophysiology of the kidney and vascular supply. Epidemiology, screening, diagnosis, and treatment interventions are covered as well as basic science, biochemical and immunological studies. The manuscript management system is completely online and includes a very quick and fair peer-review system, which is all easy to use. Visit http://www dovepress.com/testimonials.php to read real quotes from published authors. 